\title{
Effects of Cadmium Chloride on the Activity of Four Enzymes in Gills of Mosquito Fish Gambusia affinis
}

\author{
Waad S. Shahir \\ Dept. Of Biology, College of Education, \\ University of Al-Anbar
}

\section{Received}

05/09/2006

\section{Accepted}

04/04/2007

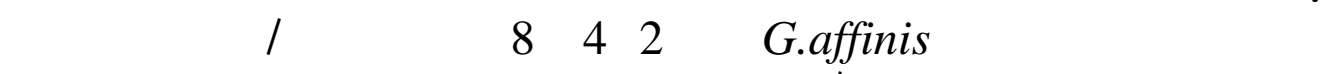

الظلاصة:

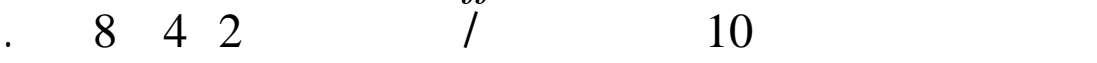

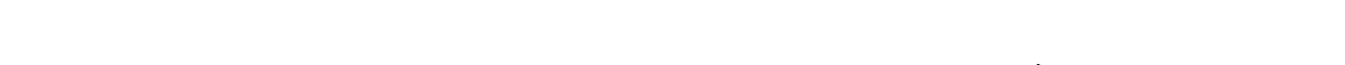

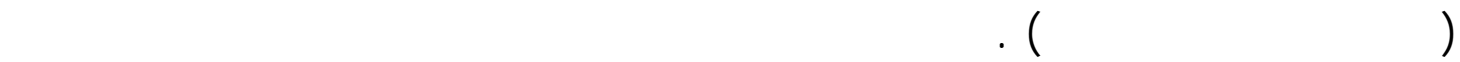

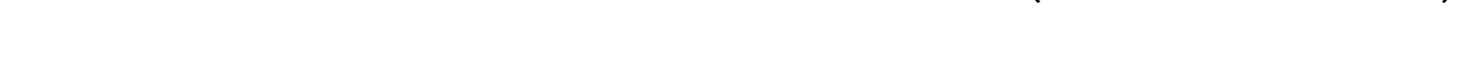

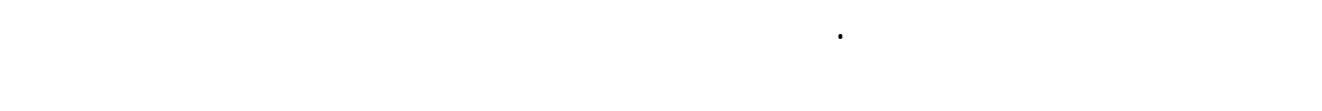

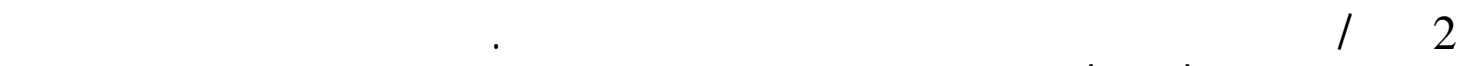

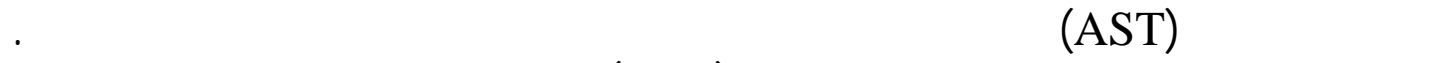

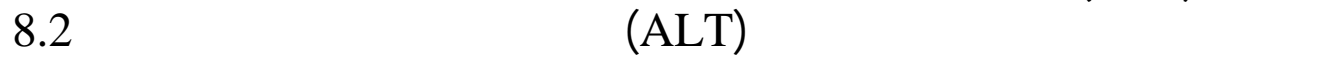

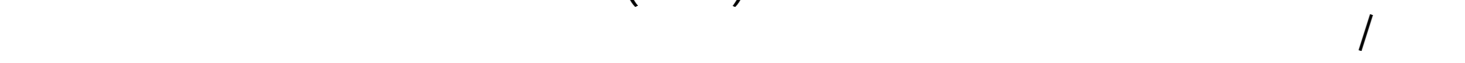

\section{Abstract :}

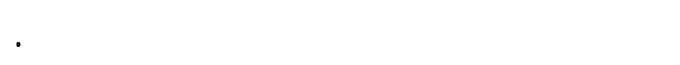

Gambusia affinis fishes were exposed to 2,4 and $8 \mathrm{mg} \mathrm{Cd} / \mathrm{L}$ of water for 8 days and for 2,4, and 8 days to $10 \mathrm{mg} \mathrm{Cd/L}$ of water. Gills were used to investigate the effect of cadmium on the activity of four enzymes measured by calorimetric methods.

There were no clear changes in the activity of Alkaline phosphatase at different concentrations but the activity increased at different periods of exposure to cadmium.

Acid phosphatase activity showed a gradual inhibition after the first concentration, while the activity increased at the different periods.

There was no change in the activity of aspartate aminotransferase (AST) at different concentrations and periods of exposure. Alanine aminotransferase (ALT) activity increased at the concentrations 2 and $8 \mathrm{mg} \mathrm{Cd} / \mathrm{L}$, but the activity increased after the first period and decreased gradually at other periods of exposure to the metal. 


\section{Introduction :}

Mosquito fish Gambusia affinis (Baird and Girard) is a widely distributed fish. From one point of view it is important in controlling diseases (biological control) such as malaria and bilharzia ${ }^{(1)}$. As well as its ability to resist changes in different ecological conditions. It is a eurythermal fish ${ }^{(2)}$ capable of living under different thermal conditions between $0-40^{\circ} \mathrm{C}$.

Biochemical parameters studied so far on the effects of cadmium chloride on different species of fishes mainly focused on synthesis and properties of metal binding proteins ${ }^{(3,4,5)}$, but little evidence is available on other soluble protein components ${ }^{(6,7,8)}$.

Some histological studies demonstrated that high cadmium exposure is known to cause bone damage, but the other studies indicated that relatively low exposure may also affect the skeleton in human. Studies on humans have indicated an effect mediated through kidney damage $^{(9,10,11)}$.

In Iraq, several studies have been carried out on the toxicity of cadmium on G. affinis ${ }^{(1,8)}$, but little (or nothing) is known about the effect of this metal at the molecular level.

The environmental changes may affect the function of animal organs, so this is, an attempt to follow up the changes in the activity of four enzymes in gills of $\boldsymbol{G}$. affinis after exposure to different concentrations of cadmium and different periods.

\section{Materials and Methods :}

Fishes used in the present work were collected from the sewage canal during October 1994 in Al-Taamim area - Al-Ramadi.

The animals were transferred to the laboratory and kept in plastic containers containing 5 liters of dechlorinated water.

Thirty individuals (Medium size) were kept in each container. Water of each container was replaced every other day. No food was provided.

Cadmium was added in the form of $\mathrm{CdCl}_{2}-2 \mathrm{H}_{2} \mathrm{O}$ at concentration 2,4 and $8 \mathrm{mg} \mathrm{Cd} / \mathrm{L}$ for one week following laboratory

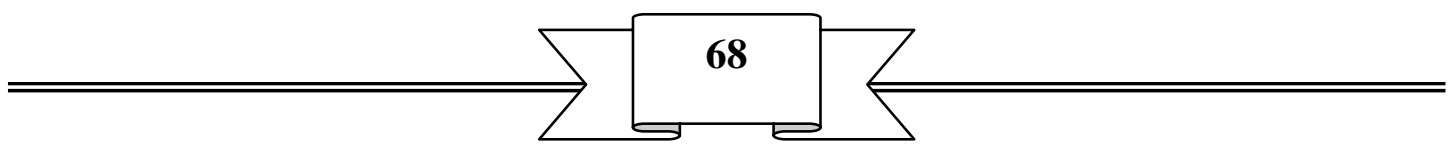




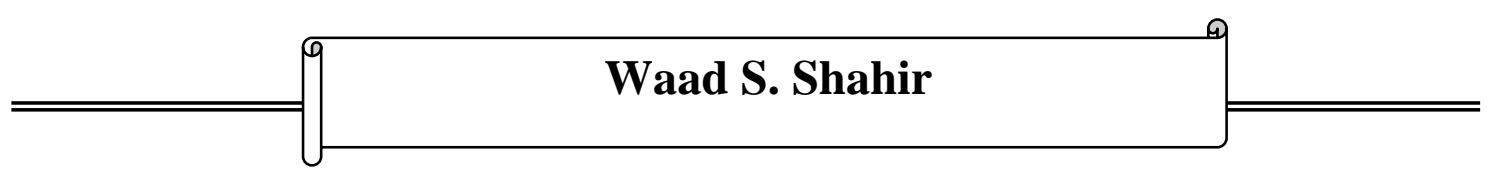

acclimation. Control animals were kept under the same conditions without addition of metal.

weighed.

Gill from the control and exposed animals were removed and

Tissues were homogenized in 5 volumes of chilled $0.1 \mathrm{M}$ Tris$\mathrm{HCl}$ buffer $\mathrm{pH} 7.2$ in a teflon pestle homogenizer. Pools from at least 20 individuals were used in each homogenation. The homogenates were centrifuged in Eppendorf centrifuge model 5412 at $2000 \mathrm{x}$ g for 10 minutes.

Assay of phosphatases and transaminases were carried out according to king and Armstrong ${ }^{(12)}$ and Reitman and Frankel ${ }^{(13)}$ respectively.

\section{Results :}

The results of the two experiments are shown in Figs. $1 \& 2$.

Alkaline phosphatase activity was found to increase to $108 \%$ at $2 \mathrm{mg} \mathrm{Cd} / \mathrm{L}$ as compared with $100 \%$ of control activity (unexposed fish to cadmium), while no significant changes in the activity were observed at other concentrations (Fig.1), however, the activity increased gradually with increasing exposure time to reach $147 \%$ at the $8^{\text {th }}$ day (Fig.2).

Acid phosphatase activity decreased gradually at 4 and $8 \mathrm{mg}$ $\mathrm{Cd} / \mathrm{L}$ to reach $62 \%$ at concentration of $8 \mathrm{mg} \mathrm{Cd} / \mathrm{L}$ Fig.1, but the activity of the enzyme showed sharp increase for 2 days of exposure to reach $153 \%$ and then decreased to $127 \%$ and $144 \%$ at the $4^{\text {th }}$ and the $8^{\text {th }}$ days respectively.

Alanine aminotransferase (ALT) activity increased to $118 \%$ and $174 \%$ at the concentrations 2 and $8 \mathrm{mg} \mathrm{Cd} / \mathrm{L}$ respectively (Fig.1), the enzyme also showed sharp increase after 2 days of exposure to cadmium, then the activity decreased gradually to about the control level (Fig.2).

There were no significant changes in the activity of aspartate aminotranserase (AST) at different concentrations and periods of exposure (Figs. 1 \& 2).

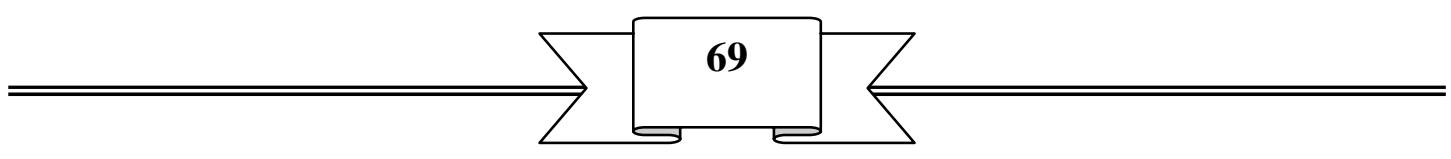




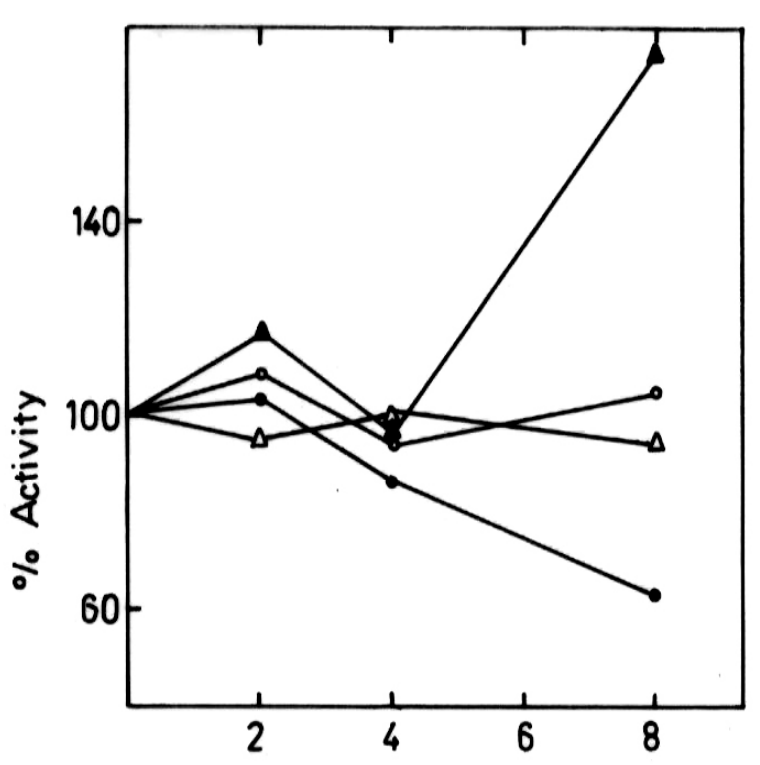

Cadmium concentration ( $\mathrm{mg} / \mathrm{l}$ )

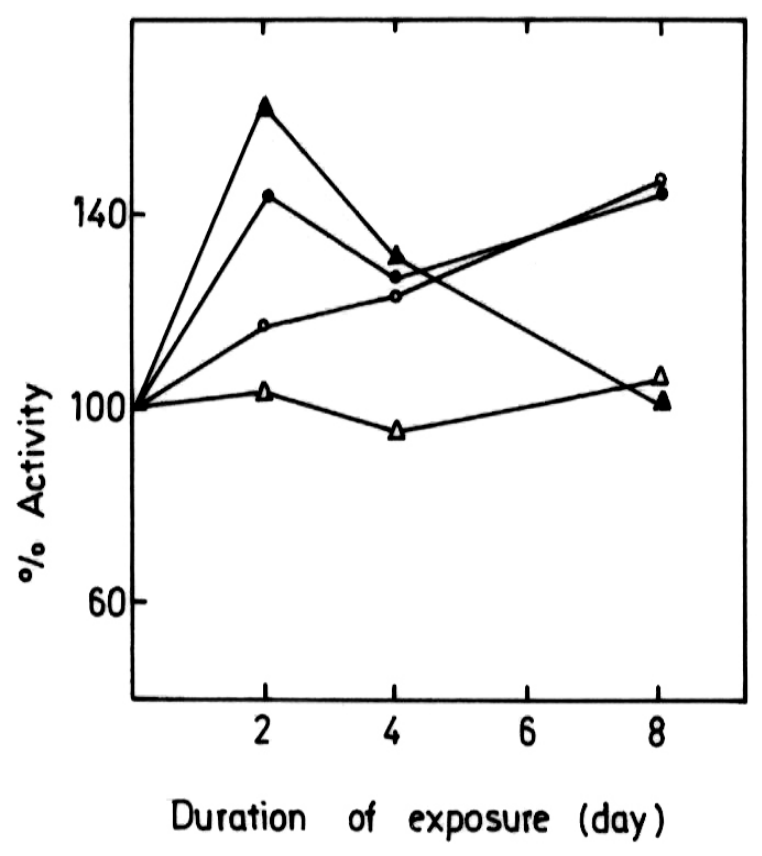

Fig.(1) Effects of cadmium on the activity of Alkaline phosphatase $(\multimap)$ Acid phosphatase $(\bullet)$ $\operatorname{AST}(\longleftarrow) \quad A L T(\longleftrightarrow)$
Fig.(2) Effects of duration of exposure on the activity of Alkaline phosphatase $(\bullet)$ Acid phosphatase $(\stackrel{\longrightarrow)}{\longrightarrow}$ $\operatorname{AST}(\square) \quad$ ALT $(\backsim)$ 




\section{Discussion :}

Studies carried out on the accumulation of heavy metals in organs of different species of fishes, such studied refer to gills as organs of high bioaccumulation rate such as in Neomacheilus barbatulus ${ }^{(14)}$, Salmo gairdneri ${ }^{(15)}$ and in Garra rufa ${ }^{(16)}$.

The results of the two experiments indicate that cadmium has a significant or non significant effect on the activities of the four enzymes studied.

There were no significant changes in activity of Alkaline phosphatase at different concentrations (Fig.1), but the activity showed a gradual increase at different periods (Fig.2).

On one hand, a decrease in alkaline phosphatase activity was observed in gills of Lepomis gibbosus ${ }^{(17)}$ and Mugil cephalus ${ }^{(7)}$. On the other hand the activity was increased in serum and livers of Mugil cephalus $^{(7)}$.

Acid phosphatase activity was inhibited at 4 and $8 \mathrm{mg} \mathrm{Cd} / \mathrm{L}$ (Fig.1), while the activity of enzymes was increased at different periods of exposure (Fig.2). This enzyme was inhibited in gills of Mugil cephalus $^{(7)}$ and liver of Fundulus heteroclitus ${ }^{(6)}$.

ALT activity increased at 2 and $8 \mathrm{mg} \mathrm{Cd} / \mathrm{L}$ (Fig.1). its activity also increased at 2 and 4 days of exposure to cadmium. ALT activation occurred in gills and heart, but inhibited in liver of Mugil cephalus ${ }^{(7)}$. ALT levels of plasma were increased in goldfish after 7 and 15 days of cadmium treatment ${ }^{(18)}$.

Cadmium showed no significant effect on the activity of AST at different concentrations and periods (Figs. $1 \& 2$ ) that is due to the activity and resistance of gills to such metal.

Finally one could conclude that the detected changes in the activities of the four enzymes may be due to specific response. Such responses in their turn may serve as indicators of early stages of toxicity.

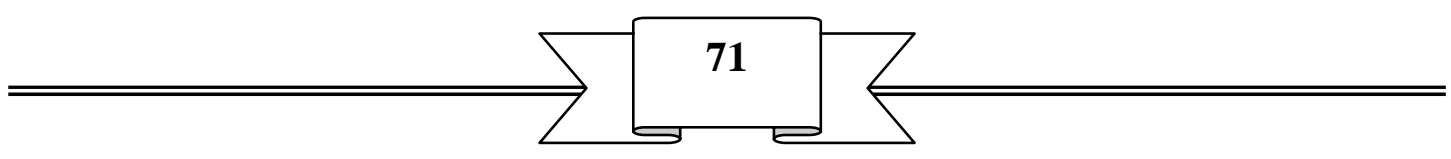




\section{References :}

1. Abdul-Hassan, J.K., Ahmed, M.K., and Abdul-Jabar, H.S., Basrah, J. Agric. Sci. 2: 103-112, (1989).

2. Winkler, D.C., Physiol. Zool 48: 367-377 (1975).

3. Benson, W.H., and Birge, W.J., Environ. Toxicol. Chem, 6: 623,629 (1987).

4. Olsson, P.E., and Hogstrand, C.I., Environ. Toxical. Chem 6 : 867870 (1987).

5. Olsson, P.E., and Haux C., Aquat. Toxicol. 9: 231-242 (1986).

6. Jackim, E., Hamlin, J.M., and Sonis, S. J. Fish Res. Bd. Can. 27: 383-390 (1970).

7. Hilmy A.M., Shabano, M.B., and Dabees, A.Y., Comp. Biochem. Physiol. 81C., 145-153 (1985).

8. Abdul-Hassan, J.K., and Kareem, D.K., Basrah, J. Agric. Sci. 2|: 71-80 (1989).

9. Akesson, A. Bjellerup, P. Lundh, T. Lidfeldt, J. Nerbrand, C. Environ. Health Perspect. 114: 830-834 (2006),

10.Alfven, T. Elinder, C.G. Hellstrom, L. Lagarde, F. Jarup, L. J. Bone Miner Res. 6: 900-905 (2004).

11.Horiguchi, H. Oguma, E. Sasaki, S. Miyamoto, K. Ikeda, Y. Machida, M. Environ. Res. 1: 83-92 (2005).

12.King, E.J., and Armstrong, A.R., Can. Med. Assoc. J. 31: 376-382 (1934).

13.Reitman, S., and Frankel, S., Am. J. Chem. Path. 28: 5-58. (1957).

14. Solbe, J.F., de. L.G., and Copper, V.A., Water Res. 10: 523 (1976).

15.Dallinger, R., and Kautzky, H., Geologia, Berlin, 82, 67, (1985).

16.Dawoud, N.D., M.Sc. Thesis, College of Education University of Mosul, (1988).

17. Plaveux, A., Hydrobiologia, 55: 251-256 (1977).

18.Zikic, R.V. Stajn, A.S. Pavlovic, S.Z. Ognjanovic, B.I. and Saicic, Z.S. Physiol. Res. 50: 105-111 (2001). 